\title{
シンボジウム C-5
}

\section{X線回折によるアクトミオシンモーターシステムの \\ 構造ダイナミックス}

若林克三、上野 豊（阪大·基礎工）

筋収縮研究の中心的課題はA T P の加水分解で駆動されるミオシンフィラメンとアク チンフィラメントの相対的な滑りや収縮力の発生の分子機構を明らかにすることである。 この目的のためX線回折は、生きた筋肉で分子レベルでの構造情報を直接提供できる唯一 の測定技術として広く利用されてきた。筋収縮の仕組みとは A T P 分解し、その化学エ ネルギーを張力という力学エネルギーに変換する機構である。これを解明するには、最終 的には化学エネルギーのリン酸間結合から蛋白分子内及び蛋白分子間結合への移動といっ た過程を原子レベルで理解することが必要である。蛋白分子の原子レベルでの構造に関し ては、X線結晶解析で蛋白分子の結晶状態の構造を調べるのが最も有効である。すでにア クトミオシン系ではミオシン分子の主要な部分（ミオシン頭部）とアクチンの構造はこの 方法で明らかにされている。しかし、解明された分子構造から、筋肉の張力発生の仕組み が直ちに分かるかといえば、そうではない。機能発現に必要な分子の動き（構造変化）は 推測するしかないからである。しかし、この動きこそが蛋白分子の機能発現にとって最も 重要な部分である。

筋肉のX線回折は、まさにアクチン.ミオシン分子の動きを調べ、力発生の分子メカ ニズムを明らかにしようとするものである。筋肉は結晶ではないから、X線解析の分解能 は低く、蛋白分子の大まかな形を捉えられるにすぎないけれども、生きた筋肉で力の発生 や短縮中のダイナミックな構造変化を力学的な量と同時に測定できるメリットは大きい。 アクチンやミオシン頭部の原子構造が明らかにされた結果、筋収縮のX線回折データもこ れを利用して解析が可能となり、ダイナミックな構造研究もアトミックなレベルに入った と云える。

本講演では、力発生や短縮中の時分割 X 線回折デー夕をまじえながら、

$\lceil 1 」$ 最大張力発生中のX線回折像の特徵と我々の解析の現状

$\lceil 2 」$ 短縮中のX線回折像の特徵

「3」アクトミオシン相互作用の新たなる疑問

を述へ、X線回折研究を通じて従来の筋収縮メカニズムの問題点を述べてみたい。 